\title{
Program Pengasuhan Positif Dengan Co-parenting Untuk Menurunkan Penerapan Pengasuhan Disfungsional
}

\author{
Positive Parenting Program with Co-parenting to Reduce \\ Dysfunctional Parenting
}

\author{
Melissa Catalina Trisnadi ${ }^{1}$, Budi Andayani ${ }^{2}$ \\ 1,2Fakultas Psikologi, Universitas Gadjah Mada
}

\begin{abstract}
This study aimed to examine the effectiveness of positive parenting programs with coparenting to reduce dysfunctional parenting. This research was conducted through a quasiexperiment with untreated control group design with dependent pretest and posttest samples and its analysis using the Mann Whitney U Test and Wilcoxon Sign Rank Test. There were 10 pairs of parent participated in this study and were divided into control and experimental groups. Dysfunctional parenting measured through the dysfunctional parenting scale which compiled by Subekti. The results proved that the "Positive Parenting Program with Co-parenting" is effective in reducing dysfunctional parenting (posttest-pretest $\mathrm{z}=-2.958, \mathrm{p}=0.003(\mathrm{p}<0.05)$ ). The results of the qualitative analysis also show that there are changes in co-parenting practices including, agreements in making rules that will be applied to children, fathers are more sensitive to the needs of partners, and the openness of expressing expectation and support needed toward partners.
\end{abstract}

Keywords: co-parenting; dysfunctional parenting; positive parenting program

Abstrak. Penelitian ini bertujuan untuk menguji efektivitas program pengasuhan positif dengan coparenting untuk menurunkan penerapan pengasuhan disfungsional. Penelitian ini dilakukan melalui eksperimen kuasi dengan desain untreated control group design with dependent pretest and posttest samples dan analisisnya menggunakan Mann Whitney U Test dan Wilcoxon Sign Rank Test. Partisipan berjumlah 10 pasang orang tua dan terbagi dalam kelompok kontrol dan eksperimen. Penerapan pengasuhan disfungsional diukur melalui skala pengasuhan disfungsional yang disusun oleh Subekti. Hasil penelitian membuktikan "Program Pengasuhan Positif Dengan Co-parenting" efektif untuk menurunkan penerapan pengasuhan disfungsional (posttest-pretest $\mathrm{z}=-2,958, \mathrm{p}=0,003$ $(\mathrm{p}<0,05))$. Hasil analisis kualitatif juga menunjukkan adanya perubahan dalam praktik co-parenting meliputi, terbentuknya kesepakatan dalam membuat aturan untuk anak, ayah lebih peka terhadap kebutuhan pasangan, dan adanya keterbukaan mengungkapkan harapan serta dukungan yang dibutuhkan pasangan.

Kata kunci: co-parenting; pengasuhan disfungsional; program pengasuhan positif

Salah satu isu penting kesehatan masyarakat yang dihadapi saat ini adalah masalah pengasuhan anak. Studi pendahuluan yang dilakukan peneliti menemukan bahwa ketidaksepakatan orang tua dalam pendisiplinan anak, kurangnya kemampuan orang tua dalam mengatasi perilaku bermasalah pada anak, stres dalam pengasuhan, dan keterbatasan informasi terkait pengasuhan merupakan beberapa permasalahan yang 
dialami oleh orang tua. Program intervensi berbasis keluarga untuk mengatasi masalah pengasuhan masih sangat terbatas. Hal ini dingkapkan oleh Sumargi et al. (2015) bahwa program parenting yang dilakukan di negara berkembang, salah satunya Indonesia masih sangat terbatas.

Di Indonesia, ditemukan fakta bahwa kekerasan dalam pengasuhan masih tergolong tinggi dan justru dilakukan di lingkungan terdekat anak yaitu keluarga. Hal ini terbukti dari penelitian Sumargi et al. (2015) yang menemukan bahwa banyak orang tua di Indonesia masih menggunakan strategi pengasuhan yang tidak efektif seperti berteriak ketika mengatasi perilaku bermasalah pada anak. Jika dilihat dengan angka, laporan Know Violence in Childhood (2017) menunjukkan 73,7\% anak-anak di Indonesia yang berumur 114 tahun mengalami pendisiplinan dengan kekerasan (violent discipline) atau agresi psikologis dan hukuman fisik di rumah. Hal ini diperkuat dengan data dari Komisi Perlindungan Anak Indonesia (KPAI) yang mencatat sebanyak 4.294 kasus kekerasan pada anak dilakukan oleh keluarga dan pengasuh (2011-2016). Kasus terbanyak terjadi pada 2013, yaitu 931 kasus kekerasan anak, namun jumlah ini terus menurun menjadi 921 kasus di 2014, 822 kasus di 2015, dan 571 kasus di 2016. Kasus kekerasan yang terjadi di rumah dan tempat pengasuhan ini berada di urutan kedua teratas, setelah persoalan anak terlibat kasus hukum yang tercatat sebanyak 7.698 kasus.

Arnold et al. (1993) menjabarkan ada tiga bentuk pengasuhan orang tua yang tidak tepat (disfungsional) dan berpengaruh pada perkembangan perilaku serta emosi anak yaitu laxness atau disiplin yang lemah (permisif), overreactivity (pendisiplinan yang bersifat otoriter, menampilkan kemarahan dan lekas marah) serta verbosity (pola asuh mengomel). Penelitian menemukan bahwa pengasuhan disfungsional menyebabkan konsekuensi negatif baik bagi orang tua maupun anak. Konsekuensi negatif yang terjadi pada anak berpengaruh pada kesehatan mental (Jaffee \& Maikovich-Fong, 2010) dan kesejahteraan anak, termasuk juga meningkatnya agresi anak (Del Vecchio \& O'Leary, 2006; Knox et al., 2011), rendahnya kemampuan akademis dan kognitif (Rodriguez \& Eden, 2008), dan gangguan tingkah laku (Tichovolsky et al., 2013). Apabila dampak negatif ini tidak ditangani dengan baik maka perilaku bermasalah pada anak akan menetap dan dapat meningkatkan risiko yang jauh lebih parah seperti kelainan mental, pengangguran, perilaku antisosial dan kriminalitas (Bayer et al., 2011, Jaffee \& Maikovich-Fong, 2010, Stevenson \& Goodman, 2001). Dampak negatif yang dialami orang tua yang tidak mampu mengatasi perilaku anak bermasalah akan mengalami stress (Sanders et al., 2005).

Salah satu program yang juga sudah banyak diterapkan untuk mengatasi penerapan pengasuhan disfungsional adalah program pengasuhan positif. Program Pengasuhan Positif merupakan teknik intervensi keluarga yang berdasar pada teori belajar sosial, bersifat multilevel, berorientasi pada tujuan preventif dalam pengasuhan dan strategi dukungan dalam keluarga. Program Pengasuhan Positif memiliki tiga tujuan utama yaitu : 1) Meningkatkan pengetahuan, kemampuan, dan kepercayaan diri orang tua dalam pengasuhan; 2) Meningkatkan pengasuhan yang aman, menyenangkan, tanpa kekerasan fisik, dan menciptakan lingkungan yang rendah konflik bagi anak; 3) meningkatkan 
kemampuan anak dalam hal sosial, emosional, bahasa, intelektual, dan perilaku melalui praktik pengasuhan positif (Sanders, 1999)

Dalam perkembangannya, beberapa penelitian mengungkapkan bahwa strategi pengasuhan menjadi lebih efektif ketika kedua orang tua sepakat pada satu pendekatan (Arnold et al., 1997) dan menerapkannya secara konsisten (Frick et al., 1999). Keterlibatan kedua orang tua dan kualitas partisipasi selama sesi program pengasuhan juga dapat memprediksi hasil program (Garvey et al., 2006; Nix et al., 2009). Namun dalam kenyataannya, menurut Lundahl et al. (2008) mengungkapkan bahwa keterlibatan ayah dalam mengikuti program pengasuhan cenderung masih kurang.

Keterlibatan orang tua dalam proses pengasuhan bersama diaplikasikan melalui pengasuhan bersama atau co-parenting. Pengasuhan bersama atau co-parenting adalah usaha bersama yang melibatkan koordinasi kedua orang tua yang bertanggung jawab terhadap pengasuhan dan keberlangsungan anak (McHale et al., 2004). Selain program pengasuhan positif, praktik pengasuhan bersama juga dapat menjadi jawaban bagi permasalahan ketidakkesepakatan orang tua dalam praktik pengasuhan. Perlu adanya pengembangan program pengasuhan yang dapat memfasilitasi orang tua dalam melakukan praktik pengasuhan positif dan praktik pengasuhan bersama (Feinberg, 2002). Kombinasi dari materi co-parenting dan materi pengasuhan akan meningkatkan keberfungsian orang tua yang lebih luas dibandingkan hanya memberikan materi co-parenting saja (Feinberg, 2002).

Tujuan dari penelitian ini adalah untuk membuktikan pengaruh program pengasuhan positif dengan co-parenting dalam menurunkan penerapan pengasuhan disfungsional.

\section{Metode}

\section{Partisipan}

Partisipan dalam penelitian adalah orang tua (ayah dan ibu) yang memiliki anak usia pra sekolah, tinggal bersama anak, memiliki skor skala pengasuhan disfungsional dalam kategori sedang atau tinggi, baik orang tua maupun anak tidak sedang menjalani terapi psikologis tertentu terkait gangguan psikis ataupun perilaku, berpendidikan terakhir adalah SMA atau sederajat dan bersedia mengikuti program pengasuhan positif dengan coparenting. Sepuluh pasang orang tua yang memenuhi kriteria menjadi partisipan dalam penelitiani ini.

\section{Rancangan Penelitian}

Penelitian menggunakan desain eksperimen untreated control group design with dependent pretest and posttest samples.

\section{Instrumen Penelitian}

Penerapan pengasuhan disfungsional diukur menggunakan skala pengasuhan disfungsional yang disusun oleh Subekti (2010), berisi 23 butir. Skala ini disusun berdasarkan aspek pengasuhan disfungsional yaitu laxness, overreactivity, dan verbosity. 
Instrumen lain yaitu modul pengasuhan positif dengan co-parenting terlebih dahulu dinilai oleh professional judgement serta diuji validitasnya melalui Aiken's V.

\section{Prosedur}

Partisipan yang memenuhi kriteria penelitian dan bersedia mengikuti penelitian, diminta untuk mengisi dan menandatangani lembar persetujuan. Peneliti juga melampirkan lembar penjelasan pelaksanaan program pengasuhan positif sehingga partisipan dapat memahami prosedur penelitian, hak serta kewajiban dari partisipan, manfaat dan konsekuensi dari keikutsertaan. Partisipan dibagi dalam dua kelompok yaitu kelompok eksperimen dan kontrol dengan metode non random assignment. Partisipan dalam kelompok eksperimen diberi perlakuan berupa program pengasuhan positif dengan co-parenting dengan tiga kali pertemuan, sedangkan kelompok kontrol tidak diberi perlakuan. Kelompok eksperimen diminta untuk mengisi skala pengasuhan disfungsional saat posttest (setelah intervensi selesai) dan follow up (2 minggu setelah intervensi selesai) sedangkan kelompok kontrol juga diminta untuk mengisi skala pengasuhan disfungsional posttest dan follow up tanpa diberi perlakuan. Intervensi pada kelompok kontrol dilakukan setelah partisipan mengisi skala pengasuhan disfungsional saat follow up.

\section{Intervensi}

Pelaksanaan program pengasuhan positif dengan co-parenting dilakukan dalam bentuk kelompok dengan tiga kali pertemuan, durasi tiap pertemuan kurang lebih 4-5 jam. Jeda antar pertemuan adalah satu minggu untuk memberi waktu bagi partisipan praktik pengasuhan positif. Program pengasuhan positif dengan co-parenting terdiri dari 7 sesi (Tabel 1).

Tabel 1.

Penjelasan Sesi-sesi dalam Program

\begin{tabular}{cll}
\hline Sesi & \multicolumn{1}{c}{ Nama Sesi } & \multicolumn{2}{c}{ Tujuan Sesi } \\
\hline 1 & Pengasuhan Positif & Memfasilitasi peserta memahami dan \\
& mempraktikkan pengasuhan positif \\
& untuk menurunkan penerapan \\
& pengasuhan disfungsional pada orang \\
& tua. \\
\hline 2 & Co-parenting & Memfasilitasi peserta dalam memahami \\
& & dan mempraktikkan pengasuhan \\
& & bersama (ayah dan ibu) untuk diterapkan \\
& ketika mengasuh anak. \\
\hline 3 & Regulasi Emosi & Memfasilitasi peserta untuk memahami \\
& & sumber stress yang dialami dan berlatih \\
& cara-cara untuk meregulasi emosi. \\
\hline
\end{tabular}




\begin{tabular}{|c|c|c|}
\hline 4 & $\begin{array}{l}\text { Memahami dan } \\
\text { Anakku }\end{array}$ & $\begin{array}{l}\text { Memfasilitasi peserta mengenal dan } \\
\text { memahami perkembangan anak usia pra } \\
\text { sekolah baik dari segi fisik, emosi dan } \\
\text { kognitif, serta permasalahan perilaku } \\
\text { yang terjadi pada anak usia prasekolah } \\
\text { sehingga orang tua mampu memberikan } \\
\text { harapan yang realistis serta pengasuhan } \\
\text { yang disesuaikan dengan tahap } \\
\text { perkembangan anak }\end{array}$ \\
\hline 5 & $\begin{array}{lll}\text { Membangun } & \text { Interaksi } & \text { Yang } \\
\text { Positif Dengan Anak } & \end{array}$ & $\begin{array}{lcr}\text { Memfasilitasi } & \text { peserta } & \text { dalam } \\
\text { meningkatkan } & \text { kemampuan } & \text { interaksi } \\
\text { dengan anak secara positif. } & \\
\end{array}$ \\
\hline 6 & Disiplin Yang Efektif & $\begin{array}{lcc}\text { Memfasilitasi } & \text { peserta } & \text { dalam } \\
\text { meningkatkan } & \text { kemampuan } & \text { untuk } \\
\text { menanamkan disiplin pada anak. } & \end{array}$ \\
\hline 7 & $\begin{array}{l}\text { Orang Tua Bahagia dan Anak } \\
\text { Bahagia }\end{array}$ & $\begin{array}{l}\text { Memfasilitasi peserta untuk saling } \\
\text { berbagi pengalaman praktik pengasuhan } \\
\text { positif yang telah dilakukan dan } \\
\text { kemajuan belajar yang telah dicapai } \\
\text { sehingga pengalaman tersebut dapat } \\
\text { meningkatkan motivasi peserta untuk } \\
\text { praktik pengasuhan positif. }\end{array}$ \\
\hline
\end{tabular}

Setelah intervensi berakhir, dilaksanakan pengukuran posttest dan dua minggu kemudian dilaksanakan pengukuran follow up.

\section{Analisis Data}

Analisis data dalam penelitian ini menggunakan uji non parametrik Mann-Whitney U dan sign-rank Wilcoxon. Analisis kualitatif juga dilakukan oleh peneliti dengan cara melihat hasil evaluasi pelaksanaan program, pengerjaan work book maupun hasil observasi.

\section{Hasil}

\section{Hasil analisis kuantitatif}

Data yang diperoleh dalam penelitian ini adalah skor penerapan pengasuhan disfungsional partisipan pada kelompok kontrol dan eksperimen yang diperoleh saat pretest, posttest dan follow up (dua minggu setelah intervensi berakhir). 


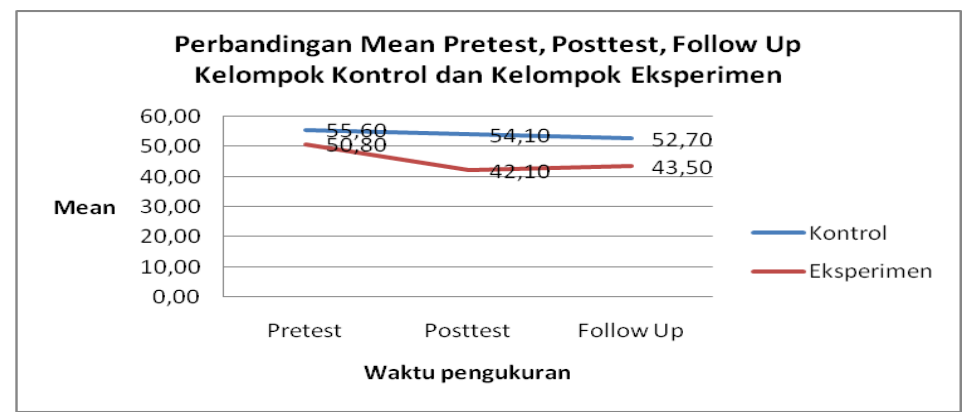

Gambar 1. Rerata (mean) skor penerapan pengasuhan disfungsional pretest, posttest dan follow up kelompok kontrol dan eksperimen

Tabel 2.

Hasil Analisis Mann Whitney U Test

\begin{tabular}{|c|c|c|c|c|c|}
\hline & Kelompok & $\begin{array}{l}\text { Mean } \\
\text { Rank }\end{array}$ & $Z$ & Sig. & Keterangan \\
\hline \multirow[t]{2}{*}{ Pretest } & Kontrol & 12,80 & \multirow{2}{*}{$-1,747$} & \multirow{2}{*}{0,081} & \multirow{2}{*}{ Tidak signifikan } \\
\hline & Eksperimen & 8,20 & & & \\
\hline \multirow{2}{*}{$\begin{array}{l}\text { Gain Score } \\
\text { (Pretest-Posttest) }\end{array}$} & Kontrol & 14,40 & \multirow{2}{*}{$-2,958$} & \multirow{2}{*}{0,003} & \multirow{2}{*}{ Signifikan } \\
\hline & Eksperimen & 6,60 & & & \\
\hline \multirow{2}{*}{$\begin{array}{l}\text { Gain Score } \\
\text { (Posttest-Follow Up) }\end{array}$} & Kontrol & 8,25 & \multirow{2}{*}{$-1,712$} & \multirow{2}{*}{0,087} & \multirow{2}{*}{ Tidak Signifikan } \\
\hline & Eksperimen & 12,75 & & & \\
\hline
\end{tabular}

Tabel 3.

Hasil Analisis Wilcoxon Sign Rank Test pada Kelompok Eksperimen

\begin{tabular}{lccc}
\hline & $\boldsymbol{Z}$ & Sig. & Keterangan \\
\hline Pretest-Posttest & $-2,603$ & 0,009 & Signifikan \\
\hline Pretest-Follow up & $-2,668$ & 0,008 & Signifikan \\
\hline Posttest-Follow up & $-1,132$ & 0,258 & Tidak Signifikan \\
\hline
\end{tabular}

Berdasarkan gambar 1, terlihat bahwa rerata skor penerapan kelompok kontrol cenderung lebih stabil, sedangkan penurunan rerata skor penerapan pengasuhan disfungsional pada kelompok eksperimen terlihat lebih tajam saat pengukuran posttest. Pada saat pengukuran follow up kelompok eksperimen mengalami kenaikkan rerata.

Uji Mann Whitney dilakukan untuk melihat pengaruh program pengasuhan positif dengan co-parenting dalam menurunkan penerapan pengasuhan disfungsional. Analisis dilakukan dengan membandingkan gain score (perubahan nilai) skor partisipan kelompok kontrol dan eksperimen. Pada tabel 1, dapat dilihat nilai signifikansi gain score (pretestposttest) sebesar $0,003(\mathrm{p}<0,05)$ menunjukkan bahwa ada perbedaan perubahan skor penerapan pengasuhan disfungsional yang signifikan antara kelompok kontrol dan eksperimen. Dilihat pada gambar 1, penurunan rerata penerapan pengasuhan disfungsional pada kelompok eksperimen lebih tinggi dibandingkan dengan kelompok kontrol. 
Penurunan skor penerapan pengasuhan disfungsional ini terbukti signifikan. Hal ini terbukti dari hasil uji wilcoxon (lihat tabel 3), nilai signifikansi (pretest-posttest) sebesar 0,008 $(\mathrm{p}<0,005)$.

Peneliti juga membandingkan gain score posttest dan follow up kelompok kontrol dan eksperimen untuk melihat efek pelatihan dalam kurun waktu dua minggu setelah program selesai. Pada tabel 1, dapat dilihat nilai signifikansi gain scor (posttest-follow up) sebesar 0,087 $(\mathrm{p}>0,05)$ menunjukkan bahwa tidak ada perbedaan perubahan skor penerapan pengasuhan disfungsional yang signifikan pada kelompok kontrol dan kelompok eksperimen antara sesudah mengikuti program dengan dua minggu setelahnya. Pada gambar 1, terlihat bahwa rerata skor penerapan pengasuhan disfungsional kelompok kontrol mengalami peningkatan. Apabila dianalisa lebih lanjut dengan melihat uji wilcoxon posttest dan follow up kelompok eksperimen (lihat tabel 3), menunjukkan kenaikkan rerata tersebut terbukti tidak signifikan. Hal ini mendukung bukti bahwa setelah dua minggu, pengaruh program pengasuhan positif dengan co-parenting terhadap partisipan masih berlangsung. Keefektifan program juga diperkuat dengan adanya penurunan skor pretest dan follow up yang signifikan pada kelompok eksperimen. Program pengasuhan positif dengan co-pareting efktif dalam menurunkan penerapan pengasuhan disfungsional.

\section{Hasil analisis kualititatif}

Secara kualitatif, partisipan mengungkapkan perubahan yang terjadi setelah mengikuti program baik dalam praktik pengasuhan maupun dalam praktik co-parenting. Perubahan dalam praktik pengasuhan meliputi meningkatnya usaha memahami anak sehingga tidak merespon dengan emosi negatif ketika mengatasi perilaku bermasalah anak, tidak memaksakan kehendak pada anak, meningkatnya interaksi yang positif dengan cara menyediakan waktu dengan anak dan adanya aturan yang disepakati bersama dalam keluarga serta rencana strategi pendisiplinan yang diterapkan pada anak. Adapun perubahan dalam praktik co-parenting yang dialami oleh partisipan meliputi, terbentuknya kesepakatan dalam membuat aturan yang akan diterapkan pada anak, ayah lebih peka terhadap kebutuhan pasangan, dan adanya keterbukaan mengungkapkan harapan serta dukungan yang dibutuhkan pasangan.

Dalam penelitian juga tampak beberapa partisipan mengalami kenaikkan skor penerapan pengasuhan disfungsional, hal ini disebabkan karena adanya faktor peristiwa eksternal yang dialami partisipan dan karakteristik personal partisipan. Dalam pelaksanaan program telah sesuai dengan rancangan penelitian.

\section{Diskusi}

Penelitian ini bertujuan untuk menguji pengaruh program pengasuhan positif dengan $\mathrm{co}^{-}$ parenting untuk menurunkan penerapan pengasuhan disfungsional. Berdasarkan hasil penelitian membuktikan bahwa program pengasuhan positif dengan co-parenting berpengaruh pada penurunan penerapan pengasuhan disfungsional. 
Pada sesi pertama, partisipan dilatih untuk memahami prinsip pengasuhan positif dalam mengasuh anak sehingga diharapkan dapat menurunkan penerapan pengasuhan disfungsional. Pada sesi ini, orang tua juga diajak untuk merefleksi pengasuhan yang selama ini diterapkan pada anak dan dituntun untuk membuat target aksi pengasuhan yang lebih positif melalui pengerjaan work book. Winter et al. (2012) mengungkapkan bahwa pengetahuan praktik pengasuhan yang diberikan dalam program pengasuhan berpengaruh pada keterampilan pengasuhan dan kepercayaan diri orang tua dalam mengasuh anak.

Pada sesi kedua, partisipan dilatih untuk melakukan praktik pengasuhan bersama. Coparenting menjadi penting karena dalam penelitian menunjukkan bahwa strategi pengasuhan menjadi lebih efektif ketika kedua orang tua sepakat pada satu pendekatan (Arnold et al., 1997) dan menerapkannya secara konsisten (Frick et al., 1999). Ketidak sepakatan orang tua dalam membesarkan anak menyebabkan praktik pendisiplinan yang dilakukan orang tua menjadi tidak konsisten (Feinberg, 2002). Pembelajaran co-parenting sangat bermanfaat bagi keluarga yang memiliki anak usia balita sampai pra sekolah karena pada masa ini muncul berbagai perilaku anak bermasalah. Usaha pencegahan ini akan membantu orang tua dalam menghadapi situasi stres sehingga tidak menimbulkan pola interaksi keluarga yang negatif (Feinberg, 2002).

Pada sesi ketiga, orang tua diajarkan mengenai regulasi emosi melalui latihan relaksasi. Orang tua yang menerapkan pengasuhan disfungsional biasanya memiliki kemampuan regulasi emosi yang tidak adekuat (Morawska \& Sanders, 2007). Keterampilan relaksasi merupakan salah satu metode yang baik dalam mengatasi situasi stress dibandingkan dengan cara menghindar dari ketidaknyamanan (Hazlett-Stevens, 2008). Salah satu cara relaksasi yang banyak digunakan adalah melalui relaksasi pernafasan.

Pada sesi keempat, orang tua diajarkan mengenai tahap perkembangan anak usia pra sekolah baik dari fisik, emosi dan kognitif serta permasalahan perilaku yang terjadi pada anak usia pra sekolah. Sanders (2008) menemukan bahwa orangtua dengan pengasuhan disfungsional biasanya memiliki harapan yang tidak realistik terhadap anak. Morawska et al. (2009) dalam penelitiannya menemukan bahwa orang tua yang memiliki lebih banyak pengetahuan pengasuhan cenderung menghindari penerapan pengasuhan disfungsional. Semakin banyak pengetahuan yang dimiliki juga berpengaruh pada tingkat kepercayaan diri orang tua dalam melakukan praktik pengasuhan.

Pada sesi kelima, orang tua diajarkan keterampilan berinteraksi positif dengan anak dengan cara memberikan pujian teguran yang efektif, menggunakan berbagai ungkapan positif, dan merespon perilaku anak dengan tepat. Dari hasil penelitian program pengasuhan positif yang dilakukan di Jepang pada sekelompok orang tua, materi mengenai membangun interaksi positif diberikan pada sesi ke 2 dan hasil penelitian menunjukkan skor gaya pengasuhan disfungsional dari orang tua menurun (Wakimizu et al., 2014). Perubahan gaya pengasuhan ini didukung karena adanya materi keterampilan mendidik anak yang dapat diterima dan mudah dipraktikkan oleh orang tua, materi yang disampaikan ditulis dalam buku sehingga orang tua dapat membacanya kembali dan program pengasuhan positif mendorong orang tua untuk melakukan regulasi diri, memilih 
target dan menginternalisasi setiap materi yang diberikan dalam meningkatkan praktik pengasuhan.

Pada sesi keenam, orang tua diajarkan untuk membuat aturan dan menyepakati bersama pasangan, memberikan konsekuensi yang tepat dan keterampilan timeout. Dalam penelitian pengasuhan positif yang dilakukan pada sekelompok orang tua di Jepang, orang tua diajarkan keterampilan untuk mengatasi perilaku bermasalah pada anak. Hasil penelitian menunjukkan bahwa gaya pengasuhan disfungsional orang tua menurun (Wakimizu et al., 2014).

Pada sesi ketujuh, orang tua didorong untuk saling berbagi pengalaman praktik pengasuhan positif yang telah dilakukan dan kemajuan belajar yang telah dicapai sehingga pengalaman tersebut dapat memberi motivasi bagi masing-masing peserta. Salari et al. (2014) mengungkapkan bahwa pelaksanaan program pengasuhan positif secara kelompok dapat memberikan dukungan, persahabatan, dan masukan yang konstruktif dari orang tua lainnya, serta memberikan peluang bagi orang tua untuk mengembangkan pengalaman.

Keberhasilan program pengasuhan positif dengan co-parenting dalam menurunkan penerapan pengasuhan disfungsional dipengaruhi oleh beberapa faktor yaitu modul pelatihan yang memiliki validitas isi yang baik, kesiapan peserta pelatihan yang tampak dari keaktifan serta motivasi yang baik, struktur program pelatihan dimana materi yang disusun, metode pembelajaran dan waktu disesuaikan dengan kebutuhan dan tujuan awal program. Faktor lain adalah transfer pelatihan yang baik, hal ini dibuktikan dengan penyampaian materi dilakukan dengan jelas dan menarik, pemillihan fasilitator yang memiliki kompetensi sesuai kebutuhan dan penggunaan work book. Faktor terakhir yang juga mendukung keberhasilan program adalah penghargaan terhadap hasil pelatihan yang tampak dari perubahan praktik pengasuhan menjadi lebih positif dan praktik co-parenting yaitu adanya kesepakatan dalam pengasuhan terbukti dari terbentuknya aturan bersama.

Beberapa partisipan mengalami kenaikkan skor penerapan pengasuhan disfungsional, hal ini disebabkan karena adanya faktor peristiwa eksternal yang dialami partisipan dan karakteristik personal partisipan. Pelaksanaan program pengasuhan positif telah sesuai dengan rancangan penelitian.

Penelitian ini juga memiliki beberapa keterbatasan yaitu tidak adanya materi relapse prevention, adanya ancaman validitas internal yaitu history dan pengujian yang tidak dikendalikan oleh peneliti.

\section{Kesimpulan}

Hasil penelitian membuktikan bahwa program pengasuhan positif dengan co-parenting efektif dalam menurunkan penerapan pengasuhan disfungsional. Secara kualitatif, orang tua mengungkapkan perubahan yang terjadi setelah mengikuti program baik dalam praktik pengasuhan maupun dalam praktik co-parenting. Perubahan dalam hal pengasuhan meliputi meningkatnya usaha memahami anak sehingga tidak merespon dengan emosi negatif ketika mengatasi perilaku bermasalah pada anak, tidak memaksakan kehendak pada anak, 
meningkatnya interaksi yang positif dengan cara menyediakan waktu dengan anak dan adanya aturan yang disepakati bersama dalam keluarga serta rencana strategi pendisiplinan yang diterapkan pada anak. Sedangkan perubahan dalam praktik co-parenting meliputi, terbentuknya kesepakatan dalam membuat aturan yang akan diterapkan pada anak, ayah lebih peka terhadap kebutuhan pasangan, dan adanya keterbukaan mengungkapkan harapan serta dukungan yang dibutuhkan pasangan.

\section{Saran}

Bagi peneliti selanjutnya, disarankan untuk menambahkan rencana relapse prevention pada akhir sesi untuk meminimalisir terjadinya spontaneous recovery dan melakukan pengendalian terhadap ancaman validitas internal yaitu history dan pengujian. Berdasarkan temuan, coparenting turut berkontribusi dalam terbentuknya kesepakatan dalam mengasuh anak dan meningkatkan relasi antar orang tua. Oleh karena itu diperlukan penelitian lebih lanjut untuk melihat pengaruh co-parenting dalam menurunkan penerapan pengasuhan disfungsional.

\section{Kepustakaan}

Arnold, D. S., O'Leary, S. G., Wolff, L. S., \& Acker, M. M. (1993). The Parenting Scale: A measure of dysfunctional parenting in discipline situations. Psychological Assessment, 5(2), 137-144. https://doi.org/10.1037/1040-3590.5.2.137

Arnold, E. H., O'Leary, S. G., \& Edwards, G. H. (1997). Father involvement and self-report parenting of children with attention deficit-hyperactivity disorder. Journal of Consulting and Clinical Psychology, 65(2), 337-342. https://doi.org/10.1037/0022-006X.65.2.337

Bayer, J. K., Ukoumunne, O. C., Lucas, N., Wake, M., Szalzo, K., \& Nicholson, J. M. (2011). Risk factors for childhood mental health symptoms: National longitudinal study of Australian children. Pediatrics, 128(4), 865-879. https://doi.org/10.1542/peds.2011-0491

Del Vecchio, T., \& O'Leary, S. G. (2006). Antecedents of toddler aggression: Dysfunctional parenting in mother-toddler dyads. Journal of Clinical Child and Adolescent Psychology, 35(2), 194-202. https://doi.org/10.1207/s153

Feinberg, M. E. (2002). Co-parenting and the transition to parenthood: a frame for prevention. Clinical Child and Family Psychology Review, 5(3), 173-195. https://dx.doi.org/10.1023\%2Fa\%3A1019695015110

Frick, P. J., Christian, R. E., \& Wootton, J. M. (1999). Age trends in the association between parenting practices and conduct problems. Behavior Modification, 23(1), 106-128. https://doi.org/10.1177/0145445599231005

Garvey, C., Julion, W., Fogg, L., Kratovil, A., \& Gross, D. (2006). Measuring participation in a prevention trial with parents of young children. Research in Nursing and Health, 29(3), 212-222. https://doi.org/10.1002/nur.20127 
Hazlett-Stevens, H. (2008). Series in anxiety and related disorders.Psychological approaches to generalized anxiety disorder: A clinician's guide to assessment and treatment. Springer Science + Business Media. https://doi.org/10.1007/978-0-387-76870-0

Jaffee, S. R., \& Maikovich-Fong, A. K. (2010). Effects of chronic maltreatment and maltreatment timing on children's behavior and cognitive abilities. Journal of Child Psychology and Psychiatry, 52(2), 184-194. https://doi.org/10.1111/j.14697610.2010.02304.x

Know Violence in Childhood. (2017). Ending violence in childhood: Global report 2017. http://www.knowviolenceinchildhood.org/announcement/flagship-report-launch.html

Knox, M., Burkhart, K., \& Khuder, S. A. (2011). Parental hostility and depression as predictors of young children's aggression and conduct problems. Journal of Aggression, Maltreatment \& Trauma, 20(7), 800-811. https://doi.org/10.1080/10926771.2011.610772

McHale, J.P., Kuersten-Hogan, R., \& Rao, N. (2004). Growing points for co-parenting theory and research. Journal of Adult Development, 11(3), 221-234. https://dx.doi.org/10.1023/B:JADE.0000035629.29960.ed

Morawska, A., Sanders, M. R. (2007). Concurrent predictors of dysfunctional parenting and maternal confidence. Child: Care, Health and Development, 33(6), 757-767. https://doi.org/10.1111/j.1365-2214.2007.00758.x

Morawska, A., Winter, L., \& Sanders, M. R. (2009). Parenting knowledge and its role in the prediction of dysfunctional parenting and disruptive child behavior. Child: Care, Health and Development, 35(2), 217-226. https://doi.org/10.1111/j.1365-2214.2008.00929.x

Nix, R. L., Bierman, K. L., \& McMahon, R. J. (2009). How attendance and quality of participation affect treatment response to parent management training. Journal of Consulting and Clinical Psychology, 77(3), 429-438. https://doi.org/10.1037/a0015028

Rodriguez, M, C. \& Eden, M. A. (2008). Disciplinary styles and child abuse potential: association with indicators of positive functioning in Children with behavior problems. Journal of Child Psychiatry and Human Development, 39, 123, https://doi.org/10.1007/s10578-007-0077-2

Salari, R. S., Ralph, A., \& Sanders, M. R. (2014). An efficacy trial : Positive Parenting Program for parents of teenagers. Behaviour Change, 31(4), 291. https://doi.org/10.1017/bec.2014.23

Sanders, M.R. (1999). Triple P-Positive Parenting Program: Towards an emprically validated multilevel parenting and family support strategy for the prevention of behavior and emotional problems in children. Clinical Child and Family Psychology Review, 2, 71-90

Stevenson, J., \& Goodman, R. (2001). Association between behaviour at age 3 years and adult criminality. The British Journal of Psychiatry, 179(3), 197-202. https://doi.org/10.1192/bjp.179.3.197

Wakimizu, R., Fujioka, H., Iejima, A., Miyamoto, S. (2014). Effectiveness of group-based positive parenting program with japanesse families raising a child with developmental disabilities: A longitudinal study. Journal of Psychological Abnormalities in Children, 3(1), 1000113. 
Subekti, A.R. (2010). Program Pengasuhan Positif untuk mengurangi aspek pola pengasuhan disfungsional (Tesis master tidak dipublikasikan). Fakultas Psikologi, Universitas Gadjah Mada.

Sumargi, A., Sofronoff, K., Mowraska, A. (2015). Understanding parenting practices and parent's views of parenting programs: A survey among Indonesian parents residing in Indonesia and Australia. Journal Child and Family Study, 24, 141-160. https://doi.org/10.1007/s10826-013-9821-3

Tichovolsky, M. H., Arnold, D. H., \& Baker, C. N. (2013). Parent predictors of changes in child behavior problems. Journal of Applied Developmental Psychology, 34(6), 336-34. https://doi.org/ 10.1016/j.appdev.2013.09.001

Winter, L., Morawska, A., \& Sanders, M. R. (2012). The effect of behavioral family intervention on knowledge of effective parenting strategies. Journal of Childand Family Studies, 21, 881-890. https://doi.org/10.1007/s10826-011-9548-y 